\title{
Music, Place, and Gulf Coast Tourism since the BP Oil Spill
}

\author{
TRAVIS D. STIMELING
}

Following the April 20, 2010, explosion of the BP Deepwater Horizon and the subsequent spill of nearly five million barrels of oil into the Gulf of Mexico, Gulf Coast residents, journalists, and academics alike expressed great concern for the environmental and public health impacts of this disaster and the subsequent cleanup efforts, as well as the short- and long-term economic consequences for the primary industries that drive the economies of the Louisiana, Mississippi, Alabama, and Florida Gulf Coast: petroleum production, fishing, and tourism. ${ }^{1}$ Of particular concern to a region already hard hit by Hurricanes Katrina and Rita in 2005 and the economic downturn of 2008 was the stability of the region's tourism industry, which depends significantly on its white beaches and emerald water to attract visitors. ${ }^{2}$ As Gulf Coast historian Harvey Jackson has observed, "When the BP/Deepwater Horizon well blew and

\footnotetext{
An earlier version of this essay was presented at the "Southern Sounds/Out of Bounds" conference at the University of North Carolina at Chapel Hill in February 2014. The author would like to thank Doug Shadle, Chris Wells, Chris Wilkinson, Anne Stickley, Tyler Kinnear, Jeff Todd Titon, and the anonymous readers for their valuable suggestions and support.

${ }^{1}$ Several accounts of the events surrounding the Deepwater Horizon spill have been published. Chief among them are Stanley Reed and Alison Fitzgerald, In Too Deep: BP and the Drilling Race that Took It Down (Hoboken: John Wiley \& Sons, 2010); National Commission on the BP Deepwater Horizon Oil Spill and Offshore Drilling, Deep Water: The Gulf Oil Disaster and the Future of Offshore Drilling, Report to the President, January 2011; and Antonia Juhasz, Black Tide: The Devastating Impact of the Gulf Oil Spill (Hoboken: John Wiley \& Sons, 2011). Moreover, a scathing indictment of BP's safety failures in the years preceding the Deepwater Horizon spill is offered in Abrahm Lustgarten, Run to Failure: BP and the Making of the Deepwater Horizon Disaster (New York and London: W.W. Norton, 2012).

For more information on the scope, scale, and impact of the spill, consult Elliott A. Norse and John Amos, "Impacts, Perception, and Policy Implications of the Deepwater Horizon Oil and Gas Disaster," Environmental Law Reporter 40 (November 2010): 60-67; Jason K. Levy and Chennat Gopalakrishnan, "Promoting Ecological Sustainability and Community Resilience in the US Gulf Coast after the 2010 Deepwater Horizon Oil Spill," Journal of Natural Resources Policy Research 2, no. 3 (July 2010): 297-315; J.S. Heyworth, T.P. Clement, and J.F. Valentine, "Deepwater Horizon Oil Spill Impacts on Alabama Beaches," Hydrology and Earth System Sciences 15 (2011): 3639-49; Sharmila Devi, "Anger and Anxiety on the Gulf Coast," The Lancet 376 (9740) (August 14-20, 2010): 503-04; Linda A. McCauley, "Environments and Health: Will the BP Oil Spill Affect Our Health?” American Journal of Nursing 110, no. 9 (September 2010): 54-56; Lynn M. Grattan, et al., "The Early Psychological Impacts of the Deepwater Horizon Oil Spill on Florida and Alabama Communities,"

Environmental Health Perspectives 119, no. 6 (June 2011): 838-43; Joseph E. Aldy, "Real-time Economic Analysis and Policy Development During the BP Deepwater Horizon Oil Spill," Harvard Kennedy School Faculty Research Working Paper Series RWP11-037, September 20, 2011, 3-7, accessed December 2012, https://research.hks.harvard.edu/publications/getFile.aspx?Id=725; U.S. Library of Congress, Congressional Research Service, The Deepwater Horizon Oil Spill and the Gulf of Mexico Fishing Industry, by Harold F. Upton, CRS Report R41640 (Washington, DC: Office of Congressional Information and Publishing, February 17, 2011); U. Rashid Sumaila, et al., "Impact of the Deepwater Horizon Well Blowout on the Economics of US Gulf Fisheries," Canadian Journal of Fisheries and Aquatic Sciences 69 (2012): 499-510; Harvey H. Jackson, III, The Rise and Decline of the Redneck Riviera: An Insider's History of the Florida-Alabama Coast (Athens and London; University of Georgia Press, 2012), 269-78.

${ }^{2}$ One 2010 study has suggested that the media may have "exacerbated" the spill's economic impacts by painting a more dire portrait of the damage than what actually transpired. Lawrence C. Smith, Jr., L. Murphy Smith, and Paul A. Ashcroft, "Analysis of Environmental and Economic Damages from British Petroleum's Deepwater Horizon Oil Spill," Social Science Research Network [2010], 8-9, accessed December 19, 2012, http://ssm.com/abstract=1653078. At the same time, it should be noted that communications scholar Jesse D. Pennington has, from an analysis of June 2010 cable news coverage of the BP oil spill, observed that news anchors seldom politicized the spill or its aftermath. Jesse D. Pennington, "The Guise of Social Responsibility in Cable News: A Case Study on Partisan Framing of the Deepwater Horizon Oil Spill” (M.S. thesis, Southern Illinois University-Edwardsville, 2010), 69.
} 
oil spewed into the Gulf, everything that walked, crawled, swam, or soared became threatened. Optimism, already dampened by recession, disappeared." ${ }^{3}$ In an effort to attract visitors to the coast, BP quickly responded to concerns about the health of Gulf Coast tourism by promising to spend more than US\$179 million to support the industry between 2010 and 2013. ${ }^{4}$ Although one Associated Press report has drawn attention to wasteful spending in several Florida counties, ${ }^{5}$ the BP grants, along with other factors, have been credited with spurring increased tourism activity throughout the region. ${ }^{6}$

Among the fruits of BP's support of Gulf Coast tourism following the spill were several musicrelated projects, including a proliferation of new popular music and culture festivals stretching from Louisiana to Florida and a television advertising campaign declaring the region to be open for tourism. ${ }^{7}$ Working with numerous tourism agencies and convention and visitors bureaus, BP has constructed an image of the Gulf Coast through music festivals and tourism-related marketing that resonates with several widely held stereotypes about the region: (1) the "hospitable" American South, (2) the South as the birthplace of American popular music, and (3) the South as a place of racial binaries. ${ }^{8}$ These stereotypes raise significant questions about the environmental and ethical implications of BP's post-Deepwater Horizon musical efforts. At the same time, the programming of many BP-funded festivals indicates an equally problematic effort to rebuild the pre-spill Gulf Coast "Redneck Riviera," a place where predominantly white, working- and middle-class southerners could come to party while not being burdened by the region's cultural, economic, and environmental politics. This essay, therefore, explores the effects of such musical constructions of place on public perception of the contemporary Gulf Coast South and suggests that the deployment of these musical practices has not only worked to rehabilitate a particular image of the Gulf Coast in the wake of the Deepwater Horizon disaster but to restore BP's corporate image, as well.

The Gulf Coast tourism industry relies primarily on what economist David Throsby has called a "mass tourism" model, which he describes as "a high-volume[,] low-yield operation." The condominiums, restaurants, outlet malls, and tour companies that line Gulf Coast beaches require a constant influx of new people who can provide a capital bolus in the form of hotel and sales taxes and other revenues. ${ }^{10}$ As anthropologist Edward M. Bruner has suggested, the vast majority of "tourists seek peak experiences" that, like music festivals, are produced by local residents for tourists who "travel through

\footnotetext{
${ }^{3}$ Jackson, The Rise and Decline of the Redneck Riviera, 5.

${ }^{4}$ BP, "Promoting Tourism along the Gulf Coast," accessed February 4, 2014, http://www.bp.com/en/global/corporate/gulf-ofmexico-restoration/restoring-the-economy/promoting-tourism-along-the-gulf-coast.html. Early plans had been to extend " $\$ 25$ million to Florida and \$15 million each to Alabama, Mississippi and Louisiana." "BP Announces Tourism Grants to Four Gulf States-17 May,” accessed February 4, 2014, http://www.bp.com/en/global/corporate/press/press-releases/bp-announcestourism-grants-to-four-gulf-states---17-may-.html. See also: Russ Henderson, "BP Vows \$70M to Aid Tourism," Mobile (AL) Press-Register, May 18, 2010, reprinted in (Pascagoula) Mississippi Press, May 18, 2010.

${ }^{5}$ Associated Press, "BP Money Buys Sports Towels, Christmas Lights, Jingles,” December 29, 2011.

${ }^{6}$ Michelle Krupa, "New Orleans Tourism Breaks Record in 2011-BP Cash for Marketing Gives Industry a Boost," New Orleans Times-Picayune, March 27, 2012. For additional factors, consult: Julia Branstrator, "The Effect of Time on Consumers' Image of the Gulf Coast after the Deepwater Horizon Oil Spill," Journal of Purdue Undergraduate Research 2 (2012): 87-88.

${ }^{7}$ Connie Baggett, “BP to Spend \$16M on Coastal Tourism,” Mobile (AL) Press-Register, April 20, 2011.

${ }^{8}$ For just one of many iterations of this myth, consult Bill C. Malone and David Stricklin, Southern Music/American Music, 2nd rev. ed. (Lexington: University Press of Kentucky, 2003). It should be noted that while Malone and Stricklin suggest that "the idea of the musical South is more than myth" (1), the book does downplay non-Southern contributions to American vernacular music.

${ }^{9}$ David Throsby, The Economics of Cultural Policy (Cambridge: Cambridge University Press, 2010), 146.

${ }^{10}$ Ibid., 150, offers a discussion of how fees can provide economic sustainability to tourist communities.
} 
the sites and usually never return." 11 As Bruner and Barbara Kirschenblatt-Gimblett have demonstrated in their discussion of cultural tourism in Kenya, the peak experiences of "mass tourism routinely [recycle] dying industries, dead sites, past colonial relations, and abandoned ethnographic tropes to produce industrial parks, living historical villages, and enactments." ${ }^{12}$ Unfortunately, although niche experiencessuch as the "toxic tours" described by Phaedra C. Pezzullo ${ }^{13}$ — can certainly have the potential to raise awareness of contemporary cultural inequities, to consider their own role in perpetuating those inequities, and to change their behaviors upon their return to daily life, most mass tourism simply invites people to travel "to the margins of empire and the peripheries of modernity" simply to enjoy familiar comforts and narratives in an exotic location. ${ }^{14}$

Yet, as numerous studies_-beginning perhaps with David Whisnant's groundbreaking, three-decadeold study of the White Top Festival—have made increasingly clear, music festivals (and cultural tourism of all sorts) are not simply temporary sites where people can relax, have a nice time, and leave their daily lives behind. Rather, they are also sites in which, as Whisnant reminds us, the "politics of culture" are played out on public stages. ${ }^{15}$ Bruner offers the useful construct of a "touristic borderzone" to describe "a distinct meeting place between the tourists who come forth from their hotels and the local performers, the 'natives,' who leave their homes to engage the tourists in structured ways in predetermined localities for defined periods of time." 16 These places have great potential, as they could easily help to break down the boundaries between "tourist" and "local" and help both groups reach more nuanced understandings of each other. But, as Bruner notes, both locals and tourists are often ill-equipped to undertake such efforts. ${ }^{17}$ Locals "rework their ... cultures to construct new emergent cultures specifically for tourist audiences," while "tourists ... do not really want an ethnographic perspective" on the people who are presenting their traditions to them. ${ }^{18}$ Mass tourism might, therefore, be a particularly ineffective means for building

\footnotetext{
${ }^{11}$ Edward M. Bruner, Culture on Tour: Ethnographies of Travel (Chicago: University of Chicago Press, 2005$), 17$.

${ }^{12}$ Edward M. Bruner and Barbara Kirschenblatt-Gimblett, "Massai on the Lawn: Tourist Realism in East Africa," in Culture on Tour: Ethnographies of Travel (Chicago: University of Chicago Press, 2005), 33.

${ }^{13}$ Pezzullo notes, "[T]hrough the rhetorical performance of a toxic tour, for example, people, places, processes, and things may seem more tangible to us and, thus, we may be more persuaded to identify with or believe in their existence, their significance, and their consequence. Communicating a sense of presence, in other words, offers a means for marginalized communities to challenge feelings of alienation from the land and from each other. It is sensual." Phaedra C. Pezzullo, Toxic Tourism: Rhetorics of Pollution, Travel, and Environmental Justice (Tuscaloosa: University of Alabama Press, 2007 ), 10. ${ }^{14}$ Bruner, Culture on Tour, 10, 191.

${ }^{15}$ David E. Whisnant, All That Is Native \& Fine: The Politics of Culture in an American Region (Chapel Hill and London: The University of North Carolina Press, 1983), 181-252 (especially 185-86, 232-35). On the politics of cultural festivals, see, among others: Timothy J. Cooley, "Folk Festival as Modern Ritual in the Polish Tatra Mountains," The World of Music 41, no. 3 (1999): 31-55; Michael Ann Williams, Staging Tradition: John Lair and Sarah Gertrude Knott (Urbana and Chicago: University of Illinois Press, 2006); Rebecca Anne Curtis, “Australia's Capital of Jazz? The (Re)creation of Place, Music and Community at the Wangaratta Jazz Festival,” Australian Geographer 41, no. 1 (March 2010), 102; Sir Anril Pineda Tiatco and Amihan Bonifacio-Ramolete, "Performing the Nation Onstage: An Afterthought on the University of the Philippines Sarsuwela Festival 2009," Asian Theatre Journal 27, no. 2 (Fall 2010), 326-29; Peter Phipps, "Performances of Power: Indigenous Cultural Festivals as Globally Engaged Cultural Strategy,” Alternatives: Global, Local, Political 35 (2010): 21740; Stephen A. King, I'm Feeling the Blues Right Now: Blues Tourism in the Mississippi Delta (Jackson: University Press of Mississippi, 2011); William S. Walker, “We Don't Live Like That Anymore': Native Peoples at the Smithsonian's Festival of American Folklife, 1970-1976," American Indian Quarterly 35, no. 4 (Fall 2011): 479-514; Peter A. Galuszka, Thunder on the Mountain: Death at Massey and the Dirty Secrets Behind Big Coal (New York: St. Martin's Press, 2012), 181-82; Mary Jo Arnoldi, “From Timbuktu to Washington': Reflections on the 2003 Mali Program at the Smithsonian Folklife Festival," Africa Today 59, no. 1 (Fall 2012): 19-21.

${ }^{16}$ Bruner, Culture on Tour, 17.

${ }^{17}$ Bruner notes, "[I]n the borderzone[,] each group knows its part in the touristic drama.... In tourism, hopefully, the natives act primitive, the tourists suspend disbelief, the producers put on a superior show, and the government provides adequate infrastructure." Ibid., 18.

${ }^{18}$ Ibid., 7, 10.
} 
cultural understanding, although its ability to rebuild shattered economies (at least in the short-term) is not to be denied.

Such economic concerns were, no doubt, central to the tourism boards and convention and visitors' bureaus (CVBs) along the Gulf Coast, organizations that saw the Deepwater Horizon spill as simply the latest in a long line of economic and environmental catastrophes to hit the region. ${ }^{19}$ Rather than taking the spill as an opportunity to re-envision their economies, most of the tourist communities along the Gulf Coast tried to reassure potential visitors that the spill had not exerted a negative impact on their communities and that the region's trademark landscapes and seafood were safe and abundant. ${ }^{20}$ At the same time, however, BP was experiencing its own crisis in the weeks and months after the spill and was, like the Gulf Coast communities suffering from its mistakes, anxious to rehabilitate its brand. BP's multimillion-dollar commitment to support Gulf Coast tourism, therefore, seemed like a mutually beneficial situation: a stimulus for local tourist economies and good public relations for BP. But, as Pezzullo has noted, polluting corporations such as BP have the power to shape narratives that cast their industries in a positive light, while "the dissenting messages of toxically assaulted communities are unlikely to be heard as loudly or to be perceived as authoritative as those produced by polluting industries." ${ }^{21}$ It should not be surprising, then, that BP-funded tourism efforts on the Gulf Coast-and the music associated with them-assuage anxieties about the spill's short- and long-term impacts by drawing on familiar, romanticized understandings of the region and filtering them through the lens of corporate paternalism.

Perhaps nowhere is this process of romanticization made more evident than in the advertising campaign that BP launched shortly after the Macondo well was successfully shut in. One component of this campaign, which persisted on national news broadcasts for more than two years, was a sixty-second advertisement titled "The Gulf Coast Makes a Perfect Winter Getaway." The ad played on American cable news networks throughout the winter of 2011-12 and circulated through the BP plc YouTube channel, which also hosts dozens of videos touting BP's corporate responsibility for the post-spill cleanup effort and for the global environment writ large. ${ }^{22}$ In this commercial, representatives from the Gulf Coast tourism industry in New Orleans; Panama City, Florida; Gulf Shores, Alabama; and Biloxi, Mississippi, inform visitors that 2011 "was the Gulf's best tourism season in years" and encourage winter vacationers to travel to the Gulf to fish, golf, birdwatch, and take advantage of off-season lodging rates. Describing the Gulf as "America's getaway spot," this advertisement sought to allay potential tourists' fears about the aftermath of the Deepwater Horizon spill.

Video Example 1: BP-funded Louisiana Tourism Advertisement

View at: http://dx.doi.org/10.3998/mp.9460447.0008.202

\footnotetext{
${ }^{19}$ Charisse Jones and Rick Jervis, “Oil Spill Takes Toll on Tourism on Gulf Coast,” USA Today, June 25, 2010, http://usatoday30.usatoday.com/travel/destinations/2010-06-25-1Aspill25 CV N.htm.

${ }^{20}$ See, for example, Jason Garcia, "Florida Starts Ads to Reassure Tourists as It Awaits BP Cash," Orlando Sentinel, May 21, 2010, http://articles.orlandosentinel.com/2010-05-21/business/os-florida-oil-spill-tourism-ads-20100521 1 visit-florida-bp-plcfeeder-markets.

${ }^{21}$ Pezzullo, Toxic Tourism, 6.

${ }^{22}$ BP plc, “The Gulf Coast Makes a Perfect Winter Getaway,” posted November 212011 , https://www.youtube.com/watch?v=tO2i mMZfz4.
} 
Accompanying this pro-tourism rhetoric and images of pristine beaches, healthy seafood, romantic couples, and joyous families is a soundtrack that clearly locates these images within the physical landscape of the Gulf Coast. After a syncopated four-measure introduction (0:00-0:03), tourism officials representing the four Gulf States affected by the spill introduce each state over zydeco music featuring accordion and triangle (0:03-0:16). When the melody is repeated, a blues-inflected harmonica replaces the accordion, vaguely signifying the blues traditions of the Deep South while more than a dozen (predominantly white) tourists enjoy the landscape (0:17-0:26). The harmonica sound and syncopated feel soon give way to a Cajun two-step bridge played on a fiddle (0:26-0:44), which transitions (0:45-0:52) to an abridged performance of the accordion and harmonica segments continuing without resolution to the ad's conclusion (0:52-1:00).

The linkage of Gulf Coast tourism and regionally associated music should come as a surprise to no one, as this technique is a key component of much tourism marketing. ${ }^{23}$ As ethnomusicologist Mark DeWitt has argued, for instance, it is financially lucrative for tourist communities "to project a strong and distinctive sense of place [rather] than to leave such matters to chance." ${ }^{24}$ One need look no further than the annual "Southern Music Issue" of Oxford American for an example of this process at work. For the past three years, the state tourism boards of Alabama, Mississippi, and Louisiana have subsidized the "Southern Music Issue," while doing little to expand readers' understanding of the growing racial and ethnic diversity in the Deep South. ${ }^{25}$ For example, the 2013 "Southern Music Issue," which focuses on the music of Louisiana, features a two-page advertising layout promoting the tourism website LouisianaSoundtrack.com, which, upon clicking, opens with a short video featuring a jazz trio and encourages website visitors to "Play. Pause. Unwind." ${ }^{26}$ Moreover, the accompanying compact disc features musical genres that have been historically associated with Louisiana-zydeco, rhythm and blues, Cajun, funk, gospel, jazz, and country-while generally ignoring more contemporary musical practices such as hip hop. As a consequence, such projects work to root Louisiana music firmly in an idealized and apolitical past and to avoid engagement with contemporary politics.

Similarly, in March 2006, the Louisiana Office of Tourism launched the "Fall in Love with Louisiana All Over Again” campaign, a $\$ 7$ million print and television campaign used in Atlanta, Little Rock, and the major markets in Texas to inspire visitors to return to the state following Hurricanes Katrina and Rita. ${ }^{27}$ This campaign features a number of Louisiana celebrities-including, most notably for this

\footnotetext{
${ }^{23}$ John Connell and Chris Gibson, Sound Tracks: Popular Music, Identity and Place (London: Routledge, 2002), 236-45. See, for example, Tourism Australia's 2007 "So Where the Bloody Hell Are You?” campaign or Egypt's 2011 campaign to draw tourism back following the Arab Spring (TourismAustraliaUSA, “So Where the Bloody Hell Are You?”, posted May 11, 2007, http://www.youtube.com/watch?v=Y-ZLr9ePuj8; Hany Anber, "Egypt Tourism Commercial 2011 HD," posted January 16, 2012, https://www.youtube.com/watch?v=grBFqRtEYOE; Emad Mekay, "Egypt's Tourism Industry Faces Sharp Reversal," New York Times, February 23, 2011, http:/www.nytimes.com/2011/02/24/world/middleeast/24iht-m24late.html? r=0. ${ }^{24}$ Mark F. DeWitt, "Heritage, Tradition, and Travel: Louisiana French Culture Places on a California Dance Floor," The World of Music 41 (1999), reprinted in Accordions, Fiddles, Two Step \& Swing: A Cajun Music Reader, eds. Ryan A. Brasseaux and Kevin S. Fontenot (Lafayette: Center for Louisiana Studies, 2006), 115.

${ }^{25}$ The Oxford American, nos. 71 (November 2010); 75 (November 2011); 79 (November 2012).

${ }^{26}$ The Oxford American no. 79: 8-9; “Louisiana Soundtrack | Play. Pause. Unwind,” accessed April 24, 2014, http://louisianasoundtrack.com/.

${ }^{27}$ Louisiana Office of Tourism, "Come Fall in Love with Louisiana All Over Again: Lt. Governor Landrieu Launches Tourism Advertising Campaign,” March 7, 2006, http://www.crt.state.la.us/ltgovernor/media view.aspx?id=99; Stacey Plaisance; “Fall in Love with Louisiana All Over Again': Hurricane Ravaged State Unveils Celebrity-Studded Campaign,” Associated Press, March 8, 2006, http://www.msnbc.msn.com/id/11729002/ns/travel-destination_travel/t/fall-love-louisianaall-over-again/\#.UPBdf3c14rg. This is not to suggest, however, that such musical strategies are endemic to post-catastrophe tourism marketing. Rather, such strategies are quite common in much tourism advertisement. However, it is worth noting that the contexts in which these advertisements are viewed certainly shape the ways that we hear and view their messages.
} 
study, musicians Wynton Marsalis and Allan Toussaint—who extol the virtues of Louisiana culture to the accompaniment of a funky New Orleans street beat. Country music superstar and Louisiana native Tim McGraw then offers a brief rendition of "Louisiana Saturday Night," culminating in the sounds of a contemporary New Orleans brass band, which includes a Cajun folk yell ("ayeee") that is not commonly associated with New Orleans. As in the BP advertisement, this sixty-second spot combines the images and sounds of some of Louisiana's most familiar contributions to American music into a sonic gumbo seasoned for the tourist's palette. ${ }^{28}$

Video Example 2: BP-funded Louisiana Tourism Advertisement

View at: http://dx.doi.org/10.3998/mp.9460447.0008.202

Viewing this BP-funded advertisement, we might see the overreliance on musical essentialism and neglect of local and regional music scenes as an effort to create an idealized and romanticized American South that conforms to tourists' "southern imaginaries," not its current realities. ${ }^{29}$ As historian Anthony J. Stanonis has asserted, southerners "have so long struggled with—and even obsessed about—defining themselves to themselves as well as to the rest of the nation ... [that] the role of image creation has become crucial." ${ }^{30}$ Moreover, as Nicole King has suggested in her analysis of the Dillon County, South Carolina, tourist trap South of the Border, "the tourist trade clearly complicates southern culture while commodifying and thereby simplifying cultures." ${ }^{31}$ Consequently, BP-funded cultural tourism might be seen simultaneously as a site for Gulf Coast residents to negotiate political and economic issues of local import while also presenting an essentialized tourist image that dispelled national fears about the wellbeing of an imagined South. As ethnomusicologists Steven Saxonberg and Magdalena Waligórska have noted in their recent study of Jewish cultural tourism in Kraków, cultural tourism creates, replicates, and reinforces cultural stereotypes and can have significant consequences for the people who reside and work in tourist areas. ${ }^{32}$ Furthermore, musicologists Denise Von Glahn and Brooks Toliver have shown in their respective studies of music composed in response to tourist sites that musical constructions of place are often indelibly influenced by romanticized imagery. ${ }^{33}$ As tourism scholar John Urry has observed, such romanticization is typical of what he calls "the tourist gaze," which "is directed to features of landscape and

\footnotetext{
${ }^{28}$ RodrigueStudio, “George Rodrigue-Louisiana Tourism Ad :60 sec (2006),” posted June 22, 2007, http://www.youtube.com/watch?v=haZGgv_Zqzc. Anthony J. Stanonis traces the association between jazz and tourism to the first issue of Louisiana Tourist magazine in 1938, although he notes that "the meaning was clear: white men played jazz." Anthony J. Stanosis, Creating the Big Easy: New Orleans and the Emergence of Modern Tourism (Athens and London: University of Georgia Press, 2006), 209. See also Stanosis's discussion of "the reinvention of Mardi Gras" in Creating the Big Easy, chapter 5.

${ }^{29}$ Deborah E. Barker and Kathryn McKee, "Introduction: The Southern Imaginary," in American Cinema and the Southern Imaginary, ed. Barker and McKee (Athens: University of Georgia Press, 2011), 1-25.

${ }^{30}$ Anthony J. Stanonis, “Introduction: Selling Dixies," in Dixie Emporium: Tourism, Foodways, and Consumer Culture in the American South, ed. Anthony J. Stanonis (Athens and London: University of Georgia Press, 2008 ), 5.

${ }^{31}$ Nicole King, "Beyond the Sombrero: Identity and Power at South of the Border, 1949-2001," in Dixie Emporium:

Tourism, Foodways, and Consumer Culture in the American South, ed. Anthony J. Stanonis (Athens and London: University of Georgia Press, 2008), 166.

${ }^{32}$ See, for example, Steven Saxonberg and Magdalena Waligórska, “Klezmer in Kraków: Kitsch or Catharsis for Poles?” Ethnomusicology 50, no. 3 (Fall 2006): 433-51. On the subject of stereotype and the tourist gaze, consult Jennie Noakes, “From the Top of the Mountain': Traditional Music and the Politics of Place in the Central Appalachian Coalfields" (Ph.D. dissertation, University of Pennsylvania, 2008), 198-99.

${ }_{33}$ Denise Von Glahn, The Sounds of Place: Music and the American Landscape (Boston: Northeastern University Press, 2003), 17-63, 205-07; Brooks Toliver, "Eco-ing in the Canyon: Ferde Grofé's Grand Canyon Suite and the Transformation of Wilderness," Journal of the American Musicological Society 57, no. 2 (Summer 2004), 331-49.
} 
townscape which separate them off from everyday experience" and is shaped by tourists' sense of "anticipation, especially through daydreaming and fantasy, of intense pleasures, either on a different scale or involving different senses from those customarily encountered." ${ }^{34}$ It should come as no surprise, then, that advertisements seeking to appeal to the tourist gaze might make extensive use of music that evokes exotic stereotypes about the places they are trying to entice tourists to visit.

Although efforts to appeal to tourists through the exotic sounds of stereotypical vernacular music are nothing new, the advertisements under consideration here become especially problematic when viewed and heard in light of the changing demographics of the American South as a whole and the Gulf Coast, in particular. Although many Americans_and, in fact, many southerners-might think of an American South populated almost exclusively by Euro-Americans and African Americans, the influx of immigrants from Asia and Central and South America in the past two decades has changed the racial and ethnic composition of the southern population. ${ }^{35}$ In particular, the Gulf Coast is now home to thousands of Vietnamese immigrants, many of whom work in Louisiana's seafood industry and have borne many of the economic consequences of the spill. ${ }^{36}$ Additionally, as Jackson has noted in his recent history of tourism along the Florida-Alabama Gulf Coast, the past two decades witnessed significant public outcry toward the wave of Mexican and Central American immigrants who were lured to the Coast by the promise of work. ${ }^{37}$ Yet Jackson's study also convincingly demonstrates that the tourist trade along the "Redneck Riviera" has never reflected the broader demographic composition of the American South. Rather, through the use of Jim Crow laws, restrictive housing covenants, and anti-immigrant rhetoric, developers

\footnotetext{
${ }^{34}$ John Urry, The Tourist Gaze: Leisure and Travel in Contemporary Societies, 2nd ed. (New York: SAGE Publications, 2002), 3.

${ }^{35}$ Sam Britt, "South Asian and East Asian Ethnicities," in The New Encyclopedia of Southern Culture, Volume 6: Ethnicity, volume ed. Celeste Ray, general ed. Charles Reagan Wilson (Chapel Hill and London: The University of North Carolina Press, 2007), 72; Hannah Gill, "Latinos," in The New Encyclopedia of Southern Culture, Volume 6: Ethnicity, volume ed. Celeste Ray, general ed. Charles Reagan Wilson (Chapel Hill and London: The University of North Carolina Press, 2007), 6566.

${ }^{36}$ Britt notes that, "of the 60,000 Asians who live in Louisiana, almost half are Vietnamese" (Britt, "South Asian and East Asian Ethnicities," 79). Alphonse Vinh also notes that the Vietnamese population in the South is second only to that of the West Coast, boasting " 30 percent of the total number of Vietnamese Americans" according to the 2000 census. Alphonse Vinh, "Vietnamese," in The New Encyclopedia of Southern Culture, Volume 6: Ethnicity, volume ed. Celeste Ray, general ed. Charles Reagan Wilson (Chapel Hill and London: The University of North Carolina Press, 2007), 244. Reports estimate that as much as "one-third of those licensed fishermen working in the Gulf region are Vietnamese American" (Nalea J. Ko, "Gulf Coast Asian American Fishermen Face Uncertain Future," Pacific Citizen, August 6, 2010, http://pacificcitizen.org/node/692?page=show. See also: Jean Shiraki, "The Forgotten Fishermen: Recommendations to Support the Southeast Asian Community in the Gulf Coast," Harvard Journal of Asian American Policy Review 21 (20102011), 3; Nina Kahori Fallenbaum, "Sea Change: Gulf Coast Vietnamese Americans Look to the Future after the BP Oil Spill," Hyphen: Asian America Unabridged no. 24 (Winter 2011), http://www.hyphenmagazine.com/magazine/issue-24survival/sea-change; Juhasz, Black Tide, 150-61. Numerous reports indicate that Asians and Asian Americans have been particularly hard hit by the spill. Additionally, in April 2012, forty-one Asian American fishermen filed a federal lawsuit against BP, "claiming discrimination in the company's Vessels of Opportunity program" (Susan Buchanan, "Asian-American Fishermen Sue BP for Racial Discrimination," The Louisiana Weekly, April 30, 2012, http://www.louisianaweekly.com/asianamerican-fishermen-sue-bp-for-racial-discrimination/). Yet, when activist Thao Chi Nguyen was asked in 2012 whether he was surprised at the lack of national attention drawn to the plight of Asian and Asian American fishermen on the Gulf Coast, Nguyen responded, "Well[,] it shocks me because of the fact that we're the poorest state to begin with and we've been through all these disasters and still we don't get enough attention. It's 'oh, they're resilient, they'll get over it." (Bridge the Gulf/Institute for Southern Studies, "Troubled Waters: Discussion with Thao Chi Nguyen on Creating Alternatives for Asian American Fishers in Mississippi," accessed January 22, 2013, http://www.bridgethegulfproject.org/node/647).

${ }^{37}$ Jackson, The Rise and Decline of the Redneck Riviera, 172-73.
} 
and tourism promoters created an overwhelmingly white vacation spot, first for inland residents of Alabama and Georgia and later for snowbirds, spring breakers, and "bourgeois bohemians."38

Taking these recent demographic shifts and the more than seven-decade history of tourism along the Gulf Coast into consideration, BP's reliance on well-worn musical tropes celebrating Euro-American and African American musical traditions to rehabilitate their corporate image becomes all the more problematic. ${ }^{39}$ The noteworthy absence of diverse musical voices in BP's Gulf Coast tourism promotions and in BP-sponsored music festivals is striking in its failure to capture the changing face of the contemporary global American South. While BP's “The Gulf Coast Makes a Perfect Winter Getaway" advertisement is far from unique, BP's efforts to leverage its finances and technology infrastructure to promote tourism in this manner call for a consideration of the ways that company-funded romanticization of the Gulf Coast might be beneficial to BP's tarnished public image. As I have recently noted, energy companies and pro-energy lobbying organizations have strategically used advertising music to present themselves as environmental stewards for much of the past decade in spite of their often poor environmental records. ${ }^{40}$ In this instance, BP is not touting its green credentials, but the advertisement's effort to convince viewers that the old familiar Gulf Coast tourist destinations are still open for business and serving fresh Gulf seafood both downplays the magnitude of the Deepwater Horizon spill and squelches debate over the long-term impacts of offshore drilling in the region. Moreover, because these advertisements often appeared during news broadcasts on various cable news outlets (at least in central Illinois, where I first encountered them), the familiar sounds of Gulf Coast vernacular musics signaled an obvious conflict of interest for the very news agencies that were beholden to BP's sponsorship. ${ }^{41}$ Consequently, the sounds heard in this advertisement are far from innocuous musical invocations of a familiar place; rather, they might well be heard to drown out vital public and private discourse about the character of the communities directly affected by the Deepwater Horizon spill.

In addition to funding television and print advertising campaigns, BP's grant programs to Gulf Coast tourist agencies were used to bolster support for preexisting Gulf Coast cultural festivals and to establish new ones with the hope of attracting tourist dollars to the region. For example, an August 2010 piece in the Biloxi Sun Herald reported grants to all three Mississippi Gulf Coast counties totaling more than $\$ 2.5$ million to support the Mississippi Gulf Coast Blues and Heritage Festival and the Gautier Mullet and

\footnotetext{
${ }^{38}$ Ibid. See especially 2, 22-23, 32-33, 50. The term "bourgeois bohemian" was coined by David Brooks in Bobos in Paradise: The New Upper Class and How They Got There (New York: Simon and Schuster, 2000). Race has frequently played a role in tourism marketing in the American South since at least the 1940s, as historian Burt Buchanan has documented (Burt Buchanan, "Magnolias and Manufacturing: Southern Imagery in Mississippi’s Promotional Publications, 1945-1955," in Mediated Images of the South: The Portrayal of Dixie in Popular Culture, eds. Alison F. Slade, Dedria Givens-Carroll, and Amber J. Narro [Lanham: Lexington Books, 2012], 93).

${ }^{39}$ For more on the ethical and financial issues that corporations should consider before embarking on green marketing campaigns, consult, among others: Jacquelyn A. Ottman, The New Rules of Green Marketing: Strategies, Tools, and Inspiration for Sustainable Branding (San Francisco: Berrett-Koehler Publishers, 2011), xiv, xx, 132, 142-43; Jeffrey Hollander and Bill Breen, The Responsibility Revolution: How the Next Generation of Businesses Will Win (San Francisco: Jossey-Bass, 2010), 23-4. For criticism of BP's green marketing campaign following the Deepwater Horizon spill, consult Reed and Fitzgerald, In Too Deep, 32-4.

${ }^{40}$ Travis D. Stimeling, "Music, Television Advertising, and the Green Positioning of the Global Energy Industry in the United States," paper presented at Ecomusicologies 2012, New Orleans, LA, 2012; revised version presented as "Popular Music, Television Advertising, and the Green Marketing of the Global Energy Industry," Popular Culture Association/American Culture Association, Washington, DC, March 2013.

${ }^{41}$ Alyssa Eckman and Thomas Lindlof offer an insightful discussion of these conflicts of interest in print journalism in "Negotiating the Gray Lines: An Ethnographic Case Study of Organizational Conflict between Advertorials and News," Journalism Studies 4, no. 1 (2003): 65-77.
} 
Music Festival, among others. ${ }^{42}$ Harvey Jackson has noted that such Gulf Coast festivals can be traced to the 1980s, when newly formed tourist development councils began to embrace cultural festivals during the decade's real estate development boom, a period that witnessed the influx of yuppies seeking high-class entertainment and accommodations in the region. ${ }^{43}$ Jackson recalls, "there were shrimp festivals, fishing rodeos, seafood festivals, music festivals-just about anything that could be celebrated was celebrated." 44 Yet, following the spill, many of the region's longstanding cultural festivals were postponed or canceled, while others, such as the Plaquemines Parish Seafood Festival, went on as planned because, as Plaquemines Parish council member and festival director Keith Hinkley reported to the Times-Picayune, "if we give up on our festival, we're giving up on our fishermen and industry." 45 Additionally, some communities hosted benefit concerts and festivals to support the recovery effort, often featuring top national touring acts as headliners. ${ }^{46} \mathrm{BP}$ tourism grants, therefore, became an essential component of the post-spill recovery, although some corporate sponsorships have laid bare many of the Gulf Coast's ongoing social and economic problems-Shell Corporation's post-Katrina sponsorship of New Orleans's Jazz and Heritage Festival, to name but one example. ${ }^{47}$

Closer examination of the music showcased at BP-supported festivals suggests that festival organizers have deployed tactics similar to those seen in the BP tourism promotion advertisement, drawing heavily from musics that are commonly associated with the Gulf Coast and using the star power of national and international musical acts-typically pop, rock, and country musicians—to draw visitors to the region. For example, the Mississippi Gulf Coast Blues and Heritage Festival, held in Pascagoula on September 11-12, 2010, showcased local and regional acts including soul singers Arthur Foy, L.J. Echols, and Omar Cunningham, zydeco group Charles Taylor \& Zydeco Trouble, and local church choirs, in addition to national touring acts such as the noted southern gospel group, the Goodman Family. ${ }^{48}$ More common, however, were festivals that booked national touring acts that could appeal to tourists while giving little exposure to local and regional musicians. For instance, the two-weekend April 2012 Crawfish Music Festival in Biloxi, Mississippi, which received a BP grant to conduct a study of the event, featured Willie Clayton along with current country radio favorites the Band Perry, Montgomery Gentry, Thompson Square, and Jake Owen, at an advance admission cost of $\$ 12$ for general admission and \$30$\$ 35$ for reserved seating. ${ }^{49}$ The Seafood, Wine \& Music Festival of Panama City Beach, Florida, which in 2010 featured Lynyrd Skynyrd with the assistance of a \$150,000 grant from BP, also featured REO Speedwagon, Lorrie Morgan, the Bellamy Brothers, and the Little River Band, while the Bayou Country

\footnotetext{
42 "Recipients of BP Tourism Grants," [Biloxi, Miss.] Sun Herald (26 August 2010).

${ }^{43}$ Jackson, The Rise and Decline of the Redneck Riviera, 123-45.

${ }^{44}$ Ibid., 122.

${ }^{45}$ Molly Reid, "Grand Gesture-Grand Isle Hopes Thousands Will Head to Its Coastal Community for a Benefit Concert," The Times-Picayune, July 23, 2010; Reid, "Resilient Revelry-Plaquemines Parish Will Go Ahead with Its Seafood Festival Despite Struggling with Oil Spill Fallout," The Times-Picayune, May 28, 2010. See also: Gia Scott, "Plaquemines Parish Seafood Festival is Being Held This Weekend," The Times-Picayune, May 26, 2010; Patty Mattison, "Seafood Festival Will Go on in Belle Chasse-But Shrimp, Oysters Remain a Question," The Times-Picayune, May 28, 2010.

${ }^{46}$ Reid, "Grand Gesture"; Beatrice Robin, "Seafood to Be Served During Boomtown Festival-Event Backs Lafitte's Recovery Drive," Lafitte Lagniappe, reprinted in The Times-Picayune, October 21, 2010.

${ }^{47}$ For a discussion of the debate over Shell's sponsorship of Jazz Fest, consult Swenson, New Atlantis, 139, $217-18,231$.

${ }^{48}$ Leigh Coleman, "Blues Fest Right Place for Laid-Back Saturday Night," Sun Herald (Biloxi, MS), September 12, 2010.

${ }^{49}$ Nicole Dow, "Crawfish Music Festival Lineup Announced-The Band Perry, Montgomery Gentry among Headliners at April Event," Sun Herald (Biloxi, MS), February 8, 2012. Later reports indicated that advance sales for the Band Perry's performance exceeded 1500 tickets (Nicole Dow, "Band Perry Attracts Record Crowd," Sun Herald [Biloxi, MS], April 22, 2012).
} 
Superfest in Baton Rouge, which was supported by a $\$ 200,000$ BP grant, was headlined by country radio mainstay, Louisiana native, and BP advertisement star Tim McGraw. ${ }^{50}$

Although such programming practices were in place before the BP oil spill and were also used by festival planners who were not supported by BP funding, the continued reliance on national headlining acts to draw tourists with expendable income to the Gulf Coast lays bare the deep socioeconomic disparity between the visitors who lubricate the gears of the local economy with their dollars and those Gulf Coast residents-many of whom cannot afford to live on or near the beach itself-who are dependent upon the tourist industry for their economic survival. ${ }^{51}$ Because of their national celebrity status, these artists are in a position to demand higher guaranteed fees for their performances and often make use of elaborate stages, lighting rigs, and public address systems, the costs of which are all passed on to concertgoers. Moreover, national touring artists seldom barnstorm from one small- to medium-sized city to another, choosing instead to draw audiences living within an hour's drive or so from the concert venue. In addition to paying for a concert ticket, then, concertgoers must also own or have access to an automobile, purchase fuel, and if the drive is long enough, perhaps even rent a hotel room near the concert venue. ${ }^{52}$ As a consequence, it was unlikely that many residents of the Gulf Coast communities that were hardest hit by the Deepwater Horizon spill would have been able to afford the expense of attending the concerts and festivals hosted near their communities. Ticket prices for Pascagoula's 2010 Mississippi Gulf Coast Blues and Heritage Festival decreased as a consequence of a $\$ 47,000 \mathrm{BP}$ grant. ${ }^{53}$ But the advance ticket price of $\$ 20$ and $\$ 5$ for the "blues" and "gospel" shows, respectively, was already prohibitively high for most residents of Pascagoula, where, according to the 2010 U.S. Census, the per capita annual income was only $\$ 23,311$, the median household income was $\$ 41,829$, and the poverty rate was slightly higher than the statewide average, at $21.7 \% .^{54}$ Journalist John Swenson, in his recent chronicle of music's role in rebuilding postKatrina New Orleans, has raised similar concerns about the growing disparities between the city's residents and those tourists who attend the city's annual Jazz Fest, noting that, "with fewer blacks in the city and fewer locals able to afford the $\$ 50$ ticket, [the 2008] Jazz Fest seemed to have edged toward

\footnotetext{
${ }^{50}$ Pat Kelly, “Seafood Fest Draws 20,000," The News Herald (Panama City, FL), November 10, 2010; "EntertainmentPanama City Beach Seafood, Wine \& Music Festival,” accessed January 16, 2013, http://www.panamacitybeachfest.com/index.php?option =com content\&view=article\&id=26\&Itemid=27; Rebekah Allen, "Visitors Bureau: Superfest Can Be BR 'Signature' Event," The Advocate (Baton Rouge, LA), June 24, 2011; "When Public, Private Mix," The Advocate (Baton Rouge, LA), July 7, 2011.

${ }^{51}$ See, for example, the Hangout Beach, Music, and Arts Festival in Gulf Shores, Alabama, which has worked "to build an event with the status of events such as the Bonnaroo and Coachella festivals" by featuring such musicians as Paul Simon, Dave Matthews Band, and the Foo Fighters, among others, at a 2011 ticket price of US\$179 for a three-day pass. Lawrence Specker, "Hangout Festival Sets Dates for 2011 Event," Press-Register [Mobile, AL], November 19, 2010; David Ferrara, "Expectations Are Big for Hangout Music Festival," Press-Register [Mobile, AL], reprinted in Birmingham News, May 20, 2011; "Lineup: Hangout Music Fest," accessed January 16, 2013, http://hangoutmusicfest.com/lineup/.

For further discussion of the complexities around race at festivals in the Gulf Coast, consult Helen Regis, "Second Lines, Minstrelsy, and Contested Landscapes of New Orleans Afro-Creole Festivals," Cultural Anthropology 14, no. 4 (1999), 47378, 495-97. This is, by no means, a phenomenon that is unique to the Gulf Coast. See, for instance: Toomas Gross, "Divided over Tourism: Zapotec Responses to Mexico's 'Magical Villages Program,” Anthropological Notebooks 17, no. 3 (2011), 61-5. ${ }^{52}$ Mark Pedelty has offered an extended and thoughtful analysis of the environmental impacts associations with contemporary popular musical performance in Ecomusicology: Folk, Rock, and the Environment (Philadelphia: Temple University Press, 2012). See especially the introduction and chapters 1 and 4.

${ }^{53}$ Lawrence Specker, "Blues Festival Saturday in Pascagoula," Press-Register (Mobile, AL), September 9, 2010. See also Coleman, "Blues Fest Right Place for Laid-Back Saturday Night."

${ }^{54}$ United States Census Bureau, "Pascagoula [City] QuickFacts from the US Census Bureau," accessed January 16, 2013, http://quickfacts.census.gov/qfd/states/28/2855360.html.
} 
becoming strictly a tourist destination, and the number of Key West and Cancun T-shirts in the crowd brought that point home." 55

The music and culture festivals that have been underwritten at least in part by BP's post-Deepwater Horizon tourism grants reveal the contradictions of life in the twenty-first-century Gulf Coast. On the one hand, tourism is a significant driver of the regional economy, and music festivals that are designed to attract tourists are a logical step toward the economic recovery of a region that suffered the effects of hurricanes, oil spills, and the 2008 recession in close succession. Drawing tens of thousands of visitors to fill the region's condominiums and hotels, eat at its many restaurants, and purchase souvenirs, these festivals have infused those Gulf Coast communities that thrive on tourism with much-needed cash.

Many observers have been hopeful that these music festivals would signal the beginning of better economic times, although there is little more than anecdotal evidence to suggest that they have contributed significantly to Gulf Coast economies. For example, when journalist Danny Goldman noted that the 2011 Hangout Music Festival in Gulf Shores, Alabama, had attracted a crowd of thirty-five thousand concertgoers and "spurred ... an estimated economic impact of roughly 20,000,000 dollars to Gulf Shores and the neighboring Orange Beach area," he also expressed optimism that the festival would "be more than just an event, but rather a movement that can assist in the resurgence of the region." ${ }^{56}$ But the tourist trade also marginalizes the Gulf Coast residents who service it. In cities such as Panama City and Destin, Florida, and Gulf Shores, Alabama, workers often return home to working-class communities that were slow to be cleaned and that have been largely neglected by BP's post-spill funding. ${ }^{57}$ Consequently, many of the BP-funded music festivals along the Gulf Coast since the Deepwater Horizon spill have exacerbated the deep socioeconomic disparities between Gulf Coast tourists and the people who make their tourist experiences possible but are unable to participate in them directly. ${ }^{58}$

The cases presented here raise important questions about the environmental and ethical implications of BP's involvement in music tourism following the Deepwater Horizon oil spill. BP's music tourism efforts might be seen as an effort to draw attention away from the spill's ongoing, long-term consequences by appealing to tourists and avoiding engagement with the people who have been hardest hit by its aftermath. ${ }^{59}$ The tourist experience is nearly always designed to appeal to the visitor's essentializing gaze, and as Bonnie Canziani and Jennifer Francioni have noted in a recent literature review, "a host community [must often] view itself from the perspective of its visitors in order to sustain a viable position in the world economic and social order." ${ }^{60}$ Efforts to encourage visitors to embark on pilgrimages to a more "authentic" South that embraces the Gulf Coast's increasing cultural diversity may exert an essentializing and history-effacing force on emerging communities. ${ }^{61}$ Yet, as historian Bruce Boyd

\footnotetext{
${ }^{55}$ John Swenson, New Atlantis: Musicians Battle for the Survival of New Orleans (New York: Oxford University Press, 2011), 139.

${ }^{56}$ Danny Goldman, “A Review of the Hangout Music Festival,” accessed October 25, 2013, http://ourvinyl.com/a-review-ofthe-hangout-music-festival/.

${ }^{57}$ One might read the inequities generated by the intersections of the tourist and petrochemical industries as further evidence of what Michael Watts has described as "the... oil-based human and ecological development failures that have typically afflicted oil-producing states in the global South.” Michael Watts, "A Tale of Two Gulfs: Life, Death, and Dispossession along Two Oil Frontiers," American Quarterly 64, no. 3 (September 2012), 457.

${ }^{58}$ For further discussion of this issue in tourism, more generally, consult Urry, The Tourist Gaze, 38-39. See also chapter 4.

${ }^{59}$ Pedelty, Ecomusicology, 1-4, 13-36.

${ }^{60}$ Bonnie Canziani and Jennifer Francioni, "Gaze and Self: Host Internalization of the Tourist Gaze," in The Host Gaze in Global Tourism, ed. Omar Moufakkir and Yvette Reisinger (Oxfordshire: CABI, 2013), 20.

${ }^{61}$ For recent studies of this phenomenon, see Karen L. Cox, Dreaming of Dixie: How the South Was Created in American Popular Culture (Chapel Hill: The University of North Carolina Press, 2011), and King, I'm Feeling the Blues Right Now, 90.
} 
Raeburn has recently argued in an essay about music in post-Katrina New Orleans, "distinctions between 'authentic' (or community-based) representations of ... music and market-driven versions that conform to trends in the music industry (or bolster cultural tourism) may not matter to musicians who are primarily concerned with survival." ${ }^{\prime 2}$ Rather, tourism has undoubtedly provided a much-needed economic stimulus to communities that suffered the direct and indirect impacts of recent disasters in the Gulf Coast region.

In fact, it is important that such short-term economic gains not be dismissed casually. ${ }^{63}$ BP-funded music festivals reveal the existence of community leaders who found their own livelihoods and those of their neighbors to be threatened by an oil slick emanating, in some cases, from hundreds of miles away. These leaders did the only thing they knew to do as national and international journalists flocked to their towns to cover the spill: assure potential visitors that the beaches were still open, the seafood still safe, the music still loud, and the atmosphere still relaxing. BP's grant funding buoyed local tourism industries that were already suffering the consequences of two major hurricanes and a global economic downturn, and the BP grants have anecdotally played a key role in helping Gulf Coast communities survive in the years since the Deepwater Horizon spill. At the time of this writing (April 2014), however, BP has not announced plans to continue their tourism grant program, revealing the difficulties of sustaining projects that rely on such funding in both the immediate and distant futures. ${ }^{64}$

BP's financing of music and other culture festivals and Gulf Coast tourism marketing campaigns also promotes a dangerous attitude of corporate paternalism toward Gulf Coast residents. Notices and videos posted on BP's website highlight the company's “commitment to the Gulf," noting, for instance that "BP directly employs more than 2,300 people in the Gulf of Mexico and supports tens of thousands of additional jobs in the region." ${ }^{55}$ Recasting itself not as a faceless corporation that has polluted the beaches, estuaries, and fisheries that sustain the region but as a friendly neighbor who can provide millions of dollars to support the local economy, BP effectively silences debate about their culpability for the longterm economic, environmental, and cultural viability of the Gulf Coast. At the same time, BP has been able to undertake what appears to be a significant goodwill program of tourism support for a very small amount of money; the $\$ 179$ million that it pledged for tourism grants between 2010 and 2013 is equivalent to only 1.3 percent (or nearly five days' worth) of the corporation's 2013 earnings of $\$ 13.4$ billion. ${ }^{66}$ Such expenditures clearly do not have a significant impact on BP's finances, and they are certainly not significant enough penalties to encourage the company to consider safer energy development paradigms. They do, however, make for striking headlines that attract the attention of readers in Gulf Coast tourist communities, reassuring them that their primary industry will remain viable and quelling criticism of BP.

The potential negative consequences of BP's corporate paternalism are not limited to the Gulf Coast communities that have benefited from BP-funded music tourism. Rather, by suggesting that the

\footnotetext{
${ }^{62}$ Bruce Boyd Raeburn, "New Orleans Musicians Surviving Katrina," The Journal of American History 94, no. 3 (December 2007), 814. Music's role in New Orleans's post-Katrina recovery is also discussed in Swenson, New Atlantis, and Sara Le Menestrel and Jacques Henry, “Sing Us Back Home': Music, Place, and the Production of Locality in Post-Katrina New Orleans," Popular Music and Society 33, no. 2 (May 2010): 179-202.

${ }^{63}$ See, for instance, the nuanced discussion of the economics of post-spill tourism in Brent W. Ritchie, John C. Crotts, Anita Zehrer, and George T. Volsky, "Understanding the Effects of a Tourism Crisis: The Impact of the BP Oil Spill on Regional Lodging Demand," Journal of Travel Research 53, no. 1 (2014): 12-25.

${ }^{64}$ According to Throsby, economically sustainable projects "should produce a stable and predictable flow of net economic benefits into the future..." (The Economics of Cultural Policy, 150).

${ }^{65} \mathrm{BP}$, “Committed to the Gulf | Gulf of Mexico restoration | BP Global," accessed February 5, 2014, http://www.bp.com/en/global/corporate/gulf-of-mexico-restoration/committed-to-the-gulf.html.

${ }^{66}$ BP, “Quarterly Results and Webcast,” accessed February 5, 2014, http://www.bp.com/en/global/corporate/investors/resultsand-reporting/quarterly-results.html.
} 
Deepwater Horizon spill has not had an adverse effect on treasured tourist venues and by presenting events that do not engage meaningfully with the communities that are still struggling with the spill's lingering effects, potential visitors can be reassured that the spill was little more than a minor inconvenience that does not merit continued political action or judicial action. According to the advertisement discussed above, the Gulf Coast had returned to normal little more than a year after the Deepwater Horizon spill. Yet visits to surrounding communities-the very communities where the tourist industry's labor force live-would reveal lingering public health, environmental, and economic fallout from the spill. Unfortunately, BP-funded tourism events and advertisements attract visitors to those parts of the Gulf Coast that were among the earliest to be cleaned, ${ }^{67}$ much as the city of New Orleans reassured visitors that the French Quarter was safe and open for business following Hurricane Katrina, despite the fact that residents of the hard-hit Lower Ninth Ward still struggle to have their concerns heard in 2014. ${ }^{68}$ Consequently, in their assurances, these advertisements and festivals might be seen as a contributing factor in the abating national and international public outrage about the spill, encouraging a collective amnesia that has resulted in a lack of engagement with the ongoing cleanup efforts along the Gulf Coast or for the accountability of BP, Transocean, and other contractors involved in the explosion and subsequent spill.

Despite the apparently deleterious effects that these efforts have had on economic, environmental, and cultural sustainability along the Gulf Coast, it is also important to consider that these advertisements and festivals are not the product of a single mind. Rather, many people have participated in the planning, production, and consumption of these various tourist-related musical products, including local government, BP (and other companies), the tourist industry, and the tourists themselves. As Bruner's notion of the "touristic borderzone" suggests, "both locals and tourists engage in a coproduction [of experience]: they each take account of the other in an ever-shifting, contested, evolving borderzone of engagement." ${ }^{99}$ It is necessary, therefore, to acknowledge that each party has played a role in drawing attention away from ongoing problems related to the Deepwater Horizon spill and, in the process, perpetuating socioeconomic divisions along the Gulf Coast. As a consequence, it is essential not only to scrutinize BP's post-spill musical efforts, but also to turn the critical lens toward our own actions and inactions as media consumers and travelers.

\section{Bibliography}

Aldy, Joseph E. "Real-Time Economic Analysis and Policy Development During the BP Deepwater Horizon Oil Spill." Harvard Kennedy School Faculty Research Working Paper Series RWP11-037. September 20, 2011.

Allen, Rebekah. "Visitors Bureau: Superfest Can Be BR 'Signature' Event.” Baton Rouge Advocate, June 24, 2011.

Anber, Hany. "Egypt Tourism Commercial 2011 HD.” Posted January 16, 2012, https://www.youtube.com/watch?v=grBFqRtEYOE.

Arnoldi, Mary Jo. “'From Timbuktu to Washington': Reflections on the 2003 Mali Program at the Smithsonian Folklife Festival.” Africa Today 59, no. 1 (Fall 2012): 19-21. http://dx.doi.org/10.2979/africatoday.59.1.3.

\footnotetext{
${ }^{67}$ See, for instance, Juhasz, Black Tide, 198.

${ }^{68}$ This is a theme of much of the commentary in Swenson, New Atlantis, esp. 115, 134.

${ }^{69}$ Bruner, Culture on Tour, 18.
} 
Associated Press. “BP Money Buys Sports Towels, Christmas Lights, Jingles.” December 29, 2011.

Baggett, Connie. "BP to Spend \$16M on Coastal Tourism," Mobile Press-Register April 20, 2011.

Barker, Deborah E., and Kathryn McKee. "Introduction: The Southern Imaginary." In American Cinema and the Southern Imaginary, edited by Deborah Barker and Kathryn McKee. Athens: University of Georgia Press, 2011. 1-25.

BP. "BP Announces Tourism Grants to Four Gulf States-17 May.” Accessed February 4, 2014, http://www.bp.com/en/global/corporate/press/press-releases/bp-announces-tourism-grants-to-fourgulf-states--17-may-.html.

. "Committed to the Gulf | Gulf of Mexico restoration | BP Global." Accessed February 5, 2014, http://www.bp.com/en/global/corporate/gulf-of-mexico-restoration/committed-to-the-gulf.html.

__ . "Promoting Tourism along the Gulf Coast." Accessed February 4, 2014, http://www.bp.com/en/global/corporate/gulf-of-mexico-restoration/restoring-theeconomy/promoting-tourism-along-the-gulf-coast.html.

__. "Quarterly Results and Webcast." Accessed February 4, 2014.

http://www.bp.com/en/global/corporate/investors/results-and-reporting/quarterly-results.html.

BP plc. "The Gulf Coast Makes a Perfect Winter Getaway.” Posted 21 November 2011. https://www.youtube.com/watch?v=tO2i_mMZfz4.

Branstrator, Julia. "The Effect of Time on Consumers' Image of the Gulf Coast after the Deepwater Horizon Oil Spill." Journal of Purdue Undergraduate Research 2 (2012): 87-8.

Bridge the Gulf/Institute for Southern Studies. "Troubled Waters: Discussion with Thao Chi Nguyen on Creating Alternatives for Asian American Fishers in Mississippi.”

http://www.bridgethegulfproject.org/node/647 (accessed 22 January 2013).

Britt, Sam. "South Asian and East Asian Ethnicities." In The New Encyclopedia of Southern Culture, Volume 6: Ethnicity. Volume ed. Celeste Ray. General ed. Charles Reagan Wilson. Chapel Hill and London: The University of North Carolina Press, 2007. 72-82.

Brooks, David. Bobos in Paradise: The New Upper Class and How They Got There. New York: Simon and Schuster, 2000.

Bruner, Edward M. Culture on Tour: Ethnographies of Travel. Chicago: University of Chicago Press, 2005.

Buchanan, Burt. "Magnolias and Manufacturing: Southern Imagery in Mississippi’s Promotional

Publications, 1945-1955." In Mediated Images of the South: The Portrayal of Dixie in Popular Culture, edited by Alison F. Slade, Dedria Givens-Carroll, and Amber J. Narro. Lanham: Lexington Books, 2012. 89-105.

Buchanan, Susan. "Asian-American Fishermen Sue BP for Racial Discrimination.” The Louisiana Weekly (30 April 2012). http://www.louisianaweekly.com/asian-american-fishermen-sue-bp-for-racialdiscrimination/ (accessed 22 January 2013).

Canziani, Bonnie, and Jennifer Francioni. “Gaze and Self: Host Internalization of the Tourist Gaze.” In The Host Gaze in Global Tourism, edited by Omar Moufakkir and Yvette Reisinger. Oxfordshire: CABI, 2013. 19-32.

Coleman, Leigh. "Blues Fest Right Place for Laid-Back Saturday Night.” [Biloxi, Miss.] Sun Herald (12 September 2010).

Connell, John, and Chris Gibson. Sound Tracks: Popular Music, Identity and Place. London: Routledge, 2002. 
Cooley, Timothy J. "Folk Festival as Modern Ritual in the Polish Tatra Mountains." The World of Music 41, no. 3 (1999): 31-55.

Cox, Karen L. Dreaming of Dixie: How the South Was Created in American Popular Culture. Chapel Hill: The University of North Carolina Press, 2011.

Curtis, Rebecca Anne. "Australia's Capital of Jazz? The (Re)creation of Place, Music and Community at the Wangaratta Jazz Festival.” Australian Geographer 41, no. 1 (March 2010): 101-16. http://dx.doi.org/10.1080/00049180903535618.

Devi, Sharmila. "Anger and Anxiety on the Gulf Coast." The Lancet 376 (9740) (14 August-20 August 2010): 503-04. http://dx.doi.org/10.1016/S0140-6736(10)61237-8.

DeWitt, Mark F. "Heritage, Tradition, and Travel: Louisiana French Culture Places on a California Dance Floor." The World of Music 41 (1999): 57-83. Reprinted in Accordions, Fiddles, Two Step \& Swing: A Cajun Music Reader, edited by Ryan A. Brasseaux and Kevin S. Fontenot. Lafayette: Center for Louisiana Studies, 2006. 115-37.

Dow, Nicole. "Crawfish Music Festival Lineup Announecd-The Band Perry, Montgomery Gentry among Headliners at April Event.” Sun Herald (Biloxi, MS), February 8, 2012.

. "Band Perry Attracts Record Crowd." Sun Herald (Biloxi, MS), April 22, 2012.

Eckman, Alyssa, and Thomas Lindlof. "Negotiating the Gray Lines: An Ethnographic Case Study of Organizational Conflict between Advertorials and News.” Journalism Studies 4, no. 1 (2003): 65-77. http://dx.doi.org/10.1080/14616700306507.

"Entertainment_Panama City Beach Seafood, Wine \& Music Festival.” Accessed January 16, 2013. http://www.panamacitybeachfest.com/index.php?option=com_content\&view =article\&id=26\&Item $\underline{\mathrm{id}=27}$.

Fallenbaum, Nina Kahori. "Sea Change: Gulf Coast Vietnamese Americans Look to the Future after the BP Oil Spill.” Hyphen: Asian America Unabridged no. 24 (Winter 2011). Accessed January 22, 2013. http://www.hyphenmagazine.com/magazine/issue-24-survival/sea-change.

Ferrara, David. "Expectations Are Big for Hangout Music Festival.” Press-Register (Mobile, AL), reprinted in Birmingham News, May 20, 2011.

Galuszka, Peter A. Thunder on the Mountain: Death at Massey and the Dirty Secrets Behind Big Coal. New York: St. Martin’s Press, 2012.

Garcia, Jason. "Florida Starts Ads to Reassure Tourists as It Awaits BP Cash." Orlando Sentinel, May 21, 2010. http://articles.orlandosentinel.com/2010-05-21/business/os-florida-oil-spill-tourism-ads20100521_1_visit-florida-bp-plc-feeder-markets.

Gill, Hannah. "Latinos." In The New Encyclopedia of Southern Culture, Volume 6: Ethnicity. Volume editor. Celeste Ray. General ed. Charles Reagan Wilson. Chapel Hill and London: The University of North Carolina Press, 2007. 65-72.

Goldman, Danny. “A Review of the Hangout Music Festival.” Accessed October 25, 2013. http://ourvinyl.com/a-review-of-the-hangout-music-festival/.

Grattan, Lynn M., et al. "The Early Psychological Impacts of the Deepwater Horizon Oil Spill on Florida and Alabama Communities." Environmental Health Perspectives 119, no. 6 (June 2011): 838-43. http://dx.doi.org/10.1289/ehp.1002915.

Gross, Toomas. "Divided over Tourism: Zapotec Responses to Mexico's 'Magical Villages Program.”' Anthropological Notebooks 17, no. 3 (2011): 51-75. 
Henderson, Russ. "BP Vows $\$ 70 \mathrm{M}$ to Aid Tourism.” [Mobile, Ala.] Press-Register (Mobile, AL), reprinted in The Mississippi Press (Pascagoula, MS), May 18, 2010.

Heyworth, J.S., T.P. Clement, and J.F. Valentine. "Deepwater Horizon Oil Spill Impacts on Alabama Beaches." Hydrology and Earth System Sciences 15 (2011): 3639-49. http://dx.doi.org/10.5194/hess15-3639-2011.

Hollander, Jeffrey, and Bill Breen, The Responsibility Revolution: How the Next Generation of Businesses Will Win. San Francisco: Jossey-Bass, 2010.

Jackson, Harvey H., III. The Rise and Decline of the Redneck Riviera: An Insider's History of the FloridaAlabama Coast. Athens and London: University of Georgia Press, 2012.

Jones, Charisse, and Rick Jervis. "Oil Spill Takes Toll on Tourism on Gulf Coast.” USA Today, June 25, 2010.

Juhasz, Antonia. Black Tide: The Devastating Impact of the Gulf Oil Spill. Hoboken: John Wiley \& Sons, 2011.

Kelly, Pat. "Seafood Fest Draws 20,000," The News Herald (Panama City, FL), November 10, 2010.

King, Nicole. "Beyond the Sombrero: Identity and Power at South of the Border, 1949-2001." In Dixie Emporium: Tourism, Foodways, and Consumer Culture in the American South, edited by Anthony J. Stanonis. Athens and London: University of Georgia Press, 2008. 148-74.

King, Stephen A. I'm Feeling the Blues Right Now: Blues Tourism in the Mississippi Delta. Jackson: University Press of Mississippi, 2011.

Ko, Nalea J. "Gulf Coast Asian American Fishermen Face Uncertain Future." Pacific Citizen, 6 August 2010. http://pacificcitizen.org/node/692?page=show.

Krupa, Michelle. "New Orleans Tourism Breaks Record in 2011—BP Cash for Marketing Gives Industry a Boost." The Times-Picayune, March 27, 2012.

Le Menestrel, Sara, and Jacques Henry. “'Sing Us Back Home': Music, Place, and the Production of Locality in Post-Katrina New Orleans.” Popular Music and Society 33, no. 2 (May 2010): 179-202. http://dx.doi.org/10.1080/03007760903086151.

Levy, Jason K., and Chennat Gopalakrishnan. "Promoting Ecological Sustainability and Community Resilience in the US Gulf Coast after the 2010 Deepwater Horizon Oil Spill.” Journal of Natural Resources Policy Research 2, no. 3 (July 2010): 297-315. http://dx.doi.org/10.1080/19390459.2010.500462.

"Lineup: Hangout Music Fest.” Accessed January 16, 2013. http://hangoutmusicfest.com/lineup/.

Louisiana Office of Tourism. "Come Fall in Love with Louisiana All Over Again: Lt. Governor Landrieu Launches Tourism Advertising Campaign.” Posted March 7, 2006.

http://www.crt.state.la.us/ltgovernor/media view.aspx?id=99.

“Louisiana Soundtrack | Play. Pause. Unwind.” Accessed April 24, 2014. http://louisianasoundtrack.com/.

Lustgarten, Abrahm. Run to Failure: BP and the Making of the Deepwater Horizon Disaster. New York and London: W.W. Norton, 2012.

Malone, Bill C., and David Stricklin. Southern Music/American Music. 2nd rev. ed. Lexington: University Press of Kentucky, 2003.

Mattison, Patty. "Seafood Festival Will Go on in Belle Chasse-But Shrimp, Oysters Remain a Question." The Times-Picayune, May 28, 2010. 
McCauley, Linda A. "Environments and Health: Will the BP Oil Spill Affect Our Health?" American Journal of Nursing 110, no. 9 (September 2010): 54-6.

http://dx.doi.org/10.1097/01.NAJ.0000388266.51213.42.

Mekay, Emad. “Egypt’s Tourism Industry Faces Sharp Reversal.” New York Times, February 23, 2011.

National Commission on the BP Deepwater Horizon Oil Spill and Offshore Drilling. Deep Water: The Gulf Oil Disaster and the Future of Offshore Drilling. Report to the President, January 2011.

Noakes, Jennie. “From the Top of the Mountain': Traditional Music and the Politics of Place in the Central Appalachian Coalfields.” Ph.D. dissertation, University of Pennsylvania, 2008.

Norse, Elliott, and John Amos. "Impacts, Perception, and Policy Implications of the Deepwater Horizon Oil and Gas Disaster.” Environmental Law Reporter 40 (November 2010): 58-73.

Ottman, Jacquelyn A. The New Rules of Green Marketing: Strategies, Tools, and Inspiration for Sustainable Branding. San Francisco: Berrett-Koehler Publishers, 2011.

The Oxford American no. 71 (November 2010).

The Oxford American no. 75 (November 2011).

The Oxford American no. 79 (November 2012).

Pedelty, Mark. Ecomusicology: Rock, Folk, and the Environment. Minneapolis: University of Minnesota Press, 2012.

Pennington, Jesse D. "The Guise of Social Responsibility in Cable News: A Case Study on Partisan Framing of the Deepwater Horizon Oil Spill.” M.S. thesis, Southern Illinois UniversityEdwardsville, 2010.

Pezzullo, Phaedra C. Toxic Tourism: Rhetorics of Pollution, Travel, and Environmental Justice. Tuscaloosa: University of Alabama Press, 2007.

Phipps, Peter. "Performances of Power: Indigenous Cultural Festivals as Globally Engaged Cultural Strategy.” Alternatives: Global, Local, Political 35 (2010): 217-240.

Plaisance, Stacey. "Fall in Love with Louisiana All Over Again': Hurricane Ravaged State Unveils Celebrity-Studded Campaign.” Associated Press, March 8, 2006. http://www.msnbc.msn.com/id/11729002/ns/travel-destination_travel/t/fall-love-louisiana-all-overagain/\#.UPBdf3c14rg.

Raeburn, Bruce Boyd. "New Orleans Musicians Surviving Katrina." The Journal of American History 94, no. 3 (December 2007): 812-19. http://dx.doi.org/10.2307/25095143.

"Recipients of BP Tourism Grants.” Sun Herald (Biloxi, MS), August 26, 2010.

Reed, Stanley, and Alison Fitzgerald. In Too Deep: BP and the Drilling Race that Took It Down. Hoboken: John Wiley \& Sons, 2011.

Regis, Helen. "Second Lines, Minstrelsy, and Contested Landscapes of New Orleans Afro-Creole Festivals." Cultural Anthropology 14, no. 4 (1999): 472-504. http://dx.doi.org/10.1525/can.1999.14.4.472.

Reid, Molly. "Grand Gesture-Grand Isle Hopes Thousands Will Head to Its Coastal Community for a Benefit Concert." The Times-Picayune, July 23, 2010.

- "Resilient Revelry_Plaquemines Parish Will Go Ahead with Its Seafood Festival Despite Struggling with Oil Spill Fallout.” The Times-Picayune, May 28, 2010. 
Ritchie, Brent W., John C. Crotts, Anita Zehrer, and George T. Volsky, "Understanding the Effects of a Tourism Crisis: The Impact of the BP Oil Spill on Regional Lodging Demand," Journal of Travel Research 53, no. 1 (2014): 12-25. http://dx.doi.org/10.1177/0047287513482775.

Robin, Beatrice. "Seafood to Be Served During Boomtown Festival—Event Backs Lafitte's Recovery Drive.” Lafitte Lagniappe, reprinted in The Times-Picayune, October 21, 2010.

RodrigueStudio. "George Rodrigue_Louisiana Tourism Ad :60 sec (2006).” Posted 22 June 2007. http://www.youtube.com/watch?v=haZGgv_Zqzc.

Saxonberg, Steven, and Magdalena Waligórska. "Klezmer in Kraków: Kitsch or Catharsis for Poles?” Ethnomusicology 50, no. 3 (Fall 2006): 433-51.

Scott, Gia. "Plaquemines Parish Seafood Festival is Being Held This Weekend." The Times-Picayune, May 26, 2010.

Shiraki, Jean. "The Forgotten Fishermen: Recommendations to Support the Southeast Asian Community in the Gulf Coast." Harvard Journal of Asian American Policy Review 21 (2010-2011): 3-8.

Smith, Lawrence C., Jr., L. Murphy Smith, and Paul A. Ashcroft. "Analysis of Environmental and Economic Damages from British Petroleum's Deepwater Horizon Spill.” Social Sciences Research Network (2010). Accessed December 19, 2012. http://ssm.com/abstract=1653078.

Specker, Lawrence. "Blues Festival Saturday in Pascagoula." Press-Register (Mobile, AL), September 9, 2010.

. "Hangout Festival Sets Dates for 2011 Event." Press-Register (Mobile, AL), November 19, 2010.

Stanosis, Anthony J. Creating the Big Easy: New Orleans and the Emergence of Modern Tourism. Athens and London: University of Georgia Press, 2006.

- "Introduction: Selling Dixies." In Dixie Emporium: Tourism, Foodways, and Consumer Culture in the American South, edited by Anthony J. Stanonis. Athens and London: University of Georgia Press, 2008. 1-16.

Stimeling, Travis D. "Music, Television Advertising, and the Green Positioning of the Global Energy Industry in the United States." Paper presented at Ecomusicologies 2012, New Orleans, LA, 2012. Revised version presented as "Popular Music, Television Advertising, and the Green Marketing of the Global Energy Industry.” Popular Culture Association/American Culture Association, Washington, DC, March 2013.

Sumaila, Rashid, et al. "Impact of the Deepwater Horizon Well Blowout on the Economics of US Gulf Fisheries." Canadian Journal of Fisheries and Aquatic Sciences 69 (2012): 499-510. http://dx.doi.org/10.1139/f2011-171.

Swenson, John. New Atlantis: Musicians Battle for the Survival of New Orleans. New York: Oxford University Press, 2011.

Throsby, David. The Economics of Cultural Policy. Cambridge: Cambridge University Press, 2010. http://dx.doi.org/10.1017/CBO9780511845253.

Tiatco, Sir Anril Pineda, and Amihan Bonifacio-Ramolete. "Performing the Nation Onstage: An Afterthought on the University of the Philippines Sarsuwela Festival 2009." Asian Theatre Journal 27, no. 2 (Fall 2010): 307-32.

Toliver, Brooks. "Eco-ing in the Canyon: Ferde Grofé's Grand Canyon Suite and the Transformation of Wilderness." Journal of the American Musicological Society 57, no. 2 (Summer 2004): 325-67. http://dx.doi.org/10.1525/jams.2004.57.2.325. 
TourismAustraliaUSA. "So Where the Bloody Hell Are You?” Posted May 11, 2007.

http://www.youtube.com/watch?v=Y-ZLr9ePuj8.

Urry, John. The Tourist Gaze: Leisure and Travel in Contemporary Societies. $2^{\text {nd }}$ ed. New York: SAGE Publications, 2002.

U.S. Census Bureau. "Pascagoula [City] QuickFacts from the US Census Bureau." Accessed January 16, 2013. http://quickfacts.census.gov/qfd/states/28/2855360.html.

U.S. Library of Congress, Congressional Research Service. The Deepwater Horizon Oil Spill and the Gulf of Mexico Fishing Industry, by Harold F. Upton. CRS Report R41640. Washington, DC: Office of Congressional Information and Publishing, February 17, 2011.

Vinh, Alphonse. "Vietnamese." In The New Encyclopedia of Southern Culture, Volume 6: Ethnicity. Volume ed. Celeste Ray. General ed. Charles Reagan Wilson. Chapel Hill and London: The University of North Carolina Press, 2007. 244-46.

Von Glahn, Denise. The Sounds of Place: Music and the American Landscape. Boston: Northeastern University Press, 2003.

Walker, William S. “We Don't Live Like That Anymore': Native Peoples at the Smithsonian's Festival of American Folklife, 1970-1976.” American Indian Quarterly35, no. 4 (Fall 2011): 479-514. http://dx.doi.org/10.5250/amerindiquar.35.4.0479.

Watts, Michael. "A Tale of Two Gulfs: Life, Death, and Dispossession along Two Oil Frontiers.” American Quarterly 64, no. 3 (September 2012): 437-67. http://dx.doi.org/10.1353/aq.2012.0039.

"When Public, Private Mix." The Advocate (Baton Rouge, LA), July 7, 2011.

Whisnant, David E. All That Is Native \& Fine: The Politics of Culture in an American Region. Chapel Hill and London: The University of North Carolina Press, 1983.

Williams, Michael Ann. Staging Tradition: John Lair and Sarah Gertrude Knott. Urbana and Chicago: University of Illinois Press, 2006. 


\begin{abstract}
The April 2010 Deepwater Horizon explosion and oil spill elicited public concern for the environmental and public health impacts of this disaster, as well as its short- and long-term economic consequences for the Gulf Coast region. Of particular concern to many was the stability of the region's tourism industry, which depends significantly on its white beaches and emerald water. In response to these concerns, BP, according to a corporate press release, promised to spend more than US\$179 million to support Gulf Coast tourism between 2010 and 2013. Among their efforts were numerous music and culture festivals stretching from Louisiana to Florida and a television advertising campaign declaring the region to be open for tourism. Many of the musical by-products of BP's recovery funding seem to deny the Gulf Coast's increasing economic and cultural globalization. This essay problematizes the ways in which BP and Gulf Coast tourism organizations alike have deployed musical practices associated with the region to reinforce essentialized understandings of place in their efforts to rehabilitate the Gulf Coast's image following the Deepwater Horizon disaster. Consequently, this essay explores the potential impact of such musical constructions of place on public perception of the American South-representations that exist at the intersection of reality and romanticism-in the twenty-first century.
\end{abstract}

